\title{
DIVINE AND HUMAN AGENCY FROM THE STANDPOINT OF HISTORICALISM, SCIENTISM, AND PHENOMENOLOGICAL REALISM
}

\section{CHARLES TALIAFERRO}

St. Olaf College

\begin{abstract}
Phenomenological realism, in the tradition of Dietrich von Hildebrand, is advanced as a promising methodology for a theistic philosophy of divine and human agency. Phenomenological realism is defended in contrast to the practice of historicalism - the view that a philosophy of mind and God should always be done as part of a thoroughgoing history of philosophy, e.g. the use of examples in analytic theology should be subordinated to engaging the work of Kant and other great philosophers. The criticism of theism based on forms of naturalism that give exclusive authority to the physical sciences (or scientism) is criticized from a phenomenological, realist perspective.
\end{abstract}

Our understanding of human agency and our understanding of the ultimate nature of reality (its origin, if any, and its sustaining structure) are interwoven. As Paul Churchland observes, if one adopts a fundamentally physicalist (or materialist) account of the cosmos as a whole, it is likely one will adopt a physicalist view of human persons. "Most scientists and philosophers would cite the presumed fact that humans have their origins in 4.5 billion years of purely chemical and biological evolution as a weighty consideration in favor of expecting mental phenomena to be nothing but particularly exquisite articulation of the basic properties of matter and energy." Conversely, if one is a theist or open to theism, according to which all the matter and energy that exists (and the cosmos as a whole) is created and sustained by am omnipresent, all good, omniscient, omnipotent God, one will have more philosophical space

\footnotetext{
${ }^{1}$ Paul M. Churchland, The Engine of Reason, the Seat of the Soul (Cambridge, MA: MIT Press, 1995), 211.
} 
for understanding human agents in non-reductive terms (as more than matter and energy).

This essay is about the framework and methodology for engaging in reflection on divine and human agency. In particular, I propose we consider two obstacles that stand in the way of developing a constructive philosophy of divine and human agency in the form of what I call historicalism and scientism. Before defining these terms, I ask you to join me in a work of imagination.

Imagine that you and I are attending a meeting of philosophers and theologians when an analytic philosopher of religion named Kevin proposes to defend a coherent understanding of human and divine agency. Taking up a philosophy of human agency first (that he intends to use in developing a view of divine agency), Kevin asks us to consider the process he goes through in fixing Allison's cup of coffee in the morning. He asks us to reflect about whether his free agency would be compromised if someone had (without Kevin's knowledge) planted a chip in his brain that would create in him an urge to bring Allison coffee if it ever happened that he got distracted or, due to some irritable mood swing, the whole task bored him. Now imagine this objection is raised: "Wait a minute! What about Kant? Or Fichte? Or Hegel? Didn't they make some important contributions on the nature of selfawareness, deliberation, and causation?" In response, Kevin concedes that, of course, Kant, Fichte, Hegel, and others, are seminal contributors to these matters. And imagine Kevin goes on to plead with his audience that he was (like many analytical philosophers) simply assuming some standard, common sense notions of agency and familiarity with some widely known thought experiments (in this case, Kevin was assuming acquaintance with the work of Princeton University philosopher Harry Frankfurt). As the philosophers and theologians did not seem happy with Kevin's vantage point, imagine Kevin decides it might be better to postpone his account of human agency and so he proposes, instead, to develop a philosophical model that provide a coherent way to understand the Nicene Creed. But before Kevin can begin to develop his first power point slide, there is an objection: "How can you simply use the creed as a starting point without taking into account Schleiermacher?"

The above scenario reflects what in this essay I will be referring to as historicalism. 'Historicalism' is an invented term for the view that serious philosophical inquiry needs to be grounded in the history of philosophy such that (for example) a philosophy of God or of human 
freedom that is launched only by the kinds of examples and thought experiments we find in mainstream analytic philosophy is a very bad idea. Instead, such a philosophical investigation should be couched in terms that engage philosophical history involving (at the least) Kant, Fichte, and Hegel. From the standpoint of historicalism, to engage in philosophical theology using the creeds or Biblical texts without taking into account Schleiermacher and hermeneutics would be like exploring Lamprechtsofen, the deepest cave in the Austrian Alps, alone without a map or source of light.

In this essay I consider the historicalist challenge to a constructive, theistic account of divine and human agency, along with considering an objection that comes from what is sometimes called scientism. By 'scientism' I mean any of the wide variety of philosophical methods that give primacy to the natural sciences; scientism is represented by what are considered strict forms of naturalism. ${ }^{2}$ Historicalism and Scientism present different specific obstacles to philosophical theology; scientism is explicitly atheistic (or non-theistic) whereas historicalism is compatible with any number of theistic positions. But they both impede the kind of philosophical theology that is customary in analytical philosophy or theology: both are positions that are elitist insofar as they both involve a highly advanced, (special or elite) educated perspective on history and science. I will be contrasting historicalism and scientism with phenomenological realism, a position that is certainly well represented in the history and the philosophy of science, but it is a method that (in my view) speaks more directly to the generally well educated inquirer (one that is educated but not on the level of specialization of work in historicalism and scientism).

There are three sections that follow: the first sketches the challenge of historicalism and scientism. Section two then offers an account of phenomenological realism as a promising methodology in its own right as well as providing a healthy alternative to historicalism and scientism. I defend what I refer to as the contextual primacy of phenomenological realism and propose that philosophical, historical inquiry (as in

${ }^{2}$ Strict naturalism includes eliminative physicalism as well as philosophies that recognize the mental as real but not given any irreducible explanatory significance. On the latter view, an explanation of some event may include mental relata but these are wholly supervenient upon physical (that is, non-mental) events and laws. For an overview of various sorts of naturalism, see Naturalism co-authored by Stewart Goetz and Charles Taliaferro. 
historicalism) and the appeal to science is secondary and dependent upon what may be called the philosophical climate as opposed to what I will describe as a more general philosophical ground. A third section considers the cultural significance of phenomenological realism. I propose that phenomenological realism provides us with good reason to insure that the practice of philosophy is widespread culturally in a fashion that promotes the love of wisdom that, in turn, helps foster the foundations for a pacific, democratic republic. I refer to this general, foundation as a philosophical ground. In reference to the case of Kevin, I hope to show that his methodology is well justified in the context of a general philosophical ground, but he should address matters of history and science given certain, specific philosophical climates. The burden of section three will be to offer some guidelines on distinguishing ground and climate philosophically.

\section{A CRITIQUE OF THEISM FROM THE STANDPOINT OF HISTORICALISM AND SCIENTISM}

There are at least two reasons behind historicalism. The first may be referred to with a rhetorical questions: Why re-invent the wheel? And the second involves an appeal to humility and solidarity.

Why re-invent the wheel? For all we know, past philosophical work may have already established certain philosophical positions. For example, perhaps Kant has established definitively that we do not have am immediate grasp (or awareness) of ourselves as substantial individual subjects who endure over time. If so, shouldn't we not begin with Kevin's report of his ordinary experiences, but with Kant's arguments and conclusions in the Critique of Pure Reason? Arguably, sustained, rigorous reflection would bring to light Kant's particular reasoning, but there is no need for us to approach the topic de nova when Kant has already succeeded in establishing a cluster of relevant points. It also might be the case that Kant was a towering genius and that, without his aid, we would not be able to reproduce and confirm his arguments, but that once we are acquainted with his historically significant findings we may come to see their compelling force.

A second reason behind historicalism is that it is a reflection of intellectual humility and solidarity with philosophers and theologians of the past. We who are working in philosophy and theology today 
are inheritors of an immense body of work historically. There may be something cowardly about mindlessly accepting the results of past inquiry, but doesn't humility and an awareness of our working in continuity with past thinkers give us good reason to approach our topics historically? Arguably there would be something arrogant or a sign of a lack of gratitude in some field of inquiry to ignore past inquiry. The study of law, for example, seems especially important to approach in historical terms. To assess, for example, positivism versus natural law theory only in terms of the present moment without couching our arguments and positions historically seems quite inappropriate (especially considering the ways in which the very concept of law involves appeal to past precedence, enduring common law, and so on). Why think philosophy or theology is any different?

As for scientism, let us go back to the meeting with Kevin. Imagine that when Kevin refers to God's action, there is an objection: What sense can possibly be made referring to the action of an incorporeal being? A commonplace criticism of a theistic account of divine and human action is that it involves a Cartesian metaphysic in which an incorporeal, non-physical God causally interacts with the physical, spatially extended world. This is purportedly completely at loggerheads with a scientific philosophy, which presupposes (or assumes or asserts) that we have a clear understanding of causation in the physical world, but little to no understanding about the non-physical. Evan Fales offers this account of what counts as proper evidence, a method that explicitly rules out theism:

I suggest that we have evidence-abundant evidence- that the only sources of energy are natural ones. Our evidence is just this: whenever we are able to balance the books on the energy (and momentum) of a physical system, and find an increase or decrease, and we look hard enough for a physical explanation of that increase or decrease, we find one. There is no case in which, given sufficient understanding of a system, we have failed to find such a physical explanation. Of course, such an explanation may be lacking for a time. There are famous cases-e.g., the deviations in the orbit of Uranus, and the apparent lack of energy conservation in meson decay-that challenged this this understanding. In each such case, the books have ultimately been balanced by the discovery of a physical cause-here, Neptune and the neutrino, respectively. ${ }^{3}$

${ }^{3}$ Evan Fales, Divine Intervention: Metaphysical and Epistemological Puzzles (London: Routledge, 2010), 16. 
The success of the natural sciences are a vindication of the sufficiency of the physicalist or materialist project of accounting for the cosmos, exposing the comparative mysteriousness and opacity of theism and theistic explanations. Herman Philipse offers the following critique of theism from the standpoint of how we have a meaningful, materially based-understanding of human agency but no idea about how such agency would be coherent in the context of the non-physical:

How can one meaningfully say that God listens to our prayers, loves us, speaks to us, answers (or does not answer our supplications, etcetera), if God is also assumed to be an incorporeal being? For the stipulation that God is an incorporeal being annuls the very conditions for meaningfully applying psychological expressions to another entity, to wit, that this entity is able in principle to display forms of bodily behaviour which resemble patterns of human behaviour. In other words, the very attempt to give a meaning and a possible referent to the word 'God' as used in theism must fail, because this attempt is incoherent. ${ }^{4}$

This objection to theism has many adherents, including Michael Martin, Paul Edwards, Kai Nielson, et al. ${ }^{5}$

Evan Fales presses his case against theism by exposing the emptiness of theistic explanations. Fales asks theists to identify the mechanisms or tools that God employs in creation. Fales offers this picture of the ostensible, scientific inscrutability of theism:

Can God cause things to happen in a spatiotemporal world inhabited by matter and (if not reducible to material processes) finite minds? If God can, then it is hard to see why, in principle, this could not be discovered by scientific investigation (by which I mean here simply properly careful and controlled empirical observations and suitable inferences there from). If God cannot, then it is hard to see why He would be of any religious significance at all. He would, after all, be both impotent and unknowable. ${ }^{6}$

Fales contends that if philosophical theologians appeal to omnipotence and omniscience in an effort to fill out an account of the modus operandi

${ }^{4}$ Herman Philipse, God in the Age of Science? A Critique of Religious Reason (Oxford: Oxford University Press, 2012), 101-102.

${ }^{5}$ For a book-length treatment of this objection see my Consciousness and the Mind of God (Cambridge: Cambridge University Press, 1994).

${ }^{6}$ Evan Fales, Divine Intervention: Metaphysical and Epistemological Puzzles (London: Routledge, 2010), 2. 
of God, they are engaging in a kind of magic trick:

The theologian's appeal to these features of the divine nature [God's omnipotence and omniscience] rather resembles the waving of a magician's wand. When a magician waves his wand which with his right hand, we may reasonably wonder what, while our attention is momentarily distracted, he is doing with his left. Appeal to omnipotence and omniscience does not answer our question so much as it merely repeats it. How are we to understand divine omnipotence? How is it that God can do all the things He is understood to be able to do? Or, to put the question a bit differently: Omnipotence is a dispositional property. What categorical properties of God underwrite it, and how, exactly, do they do so?

The charge that the theistic appeal to God's power is explanatorily vacuous or unacceptably obscure is endorsed by Herman Philipse, Jan Narveson, Michael Martin, and others.

\section{HISTORICALISM AND SCIENTISM FROM THE STANDPOINT OF PHENOMENOLOGICAL REALISM}

I am using the term phenomenological realism to refer to the philosophical method employed by Dietrich von Hidebrand (his methodology has also been called realist phenomenology), shared by Max Scheler, Reinhardt Grossman, Roderick Chisholm, and, most recently, by Stan Klein.

Dietrich von Hildebrand (1889-1977) is not widely known in mainstream philosophy today, but he is very much celebrated by Roman Catholic philosophical theologians (including John Paul II) and his form of phenomenological realism has a stability and precision that (in my view) is superior to the better known German philosopher who shares in the practice of this form of phenomenology, Max Scheler. According to phenomenological realism, our primary starting point in our philosophy should be a critical study of what Hildebrand referred to as the datum of experience as this is revealed to us pre-philosophically. In the context of ethics as well as in terms of building up our general account of human nature and action, we need to apprise ourselves of what first and foremost appears to us as the data that our philosophical accounts need to address.

In order to understand this moral sphere, we must immerse ourselves, as it were, in the rich qualitative plenitude of a moral datum and

${ }^{7}$ Ibid, 3. 
bring ourselves to a full state of "wondering" about it. We must seek to analyze the datum, delve into its nature, explore its relations with other fundamental data of experience, and, finally, inquire into the presuppositions which have to be fulfilled in order that a man may be endowed with moral goodness.

In pursuit of our inquiry, however, let us be on our guard against all constructions and explanations which are incompatible with the nature of moral data as presented in experience or which in any way fail to do full justice to them. Thus we must, time and again, come back to the most explicit and unrestricted experience of moral data, and confront every result of our exploration with the full flavor of the experienced data themselves. ${ }^{8}$

Hidlebrand is quite explicit about the importance of getting to the datum that is prior to our philosophical reflections:

Before we begin the analysis of our topic, some fundamental remarks of an epistemological nature are in order. These will serve to clarify further the few introductory remarks we have made thus far. This work starts from "the immediately given," that is, from the data of experience. The reader will be able to estimate properly our results only if he is willing to hold in abeyance for a while all theories which are familiar to him, and which provide him with a set of terms which he is accustomed to use in sizing up that which is immediately given. I want to begin from the beginning, suspending all theories concerning the moral sphere. ${ }^{9}$

Hildebrand's form of phenomenology differs from Husserl (who was one of Hildebrand's teachers) insofar as he does not seek to suspend (or bracketed) judgment of what is real in the course of his phenomenological account of values or persons.

Phenomenological realists like Hildebrand, Scheler, Grossman, Chisholm, and Klein are each committed to the reality and integrity of humans as agents who act for purposes and with reasons. Moreover, they maintain that there is nothing revealed by a close study of human agency that agency itself is either necessarily (that is, exclusively) anthropomorphic nor restricted to what is physical; on this later point, they each maintain that our concept of what is physical is not as clear or intelligible as our concept of what is mental (subjective, experiential, mind). Their philosophical methodology is therefore not adverse (or, put

\footnotetext{
${ }^{8}$ Dietrich von Hildebrand, Christian Ethics, (New York: McKay, 1952), 1.

${ }^{9}$ ibid, 2.
} 
more positively, their methodology is genuinely open) to the coherence and plausibility of theism.

Consider again the challenge of historicalism, the view that appeals to what seems experientially evident have been thoroughly undermined by philosophers of the past. Simply to assume we know what we are talking about when using (for example) Harry Frankfurt cases of when a person acts freely in the absence (or presence) of alternative possibilities is to shirk our duty as philosophers to take seriously Kant's view that the self is unobservable (a view shared by Hume, among others) and any number of incompatible alternatives (Nietzsche versus Parfit versus Kim ...) and so on. Let us return to the case of Kevin. What struck philosophers and theologians at the imagined meeting is that Kevin did not begin his presentation by indicating why he seems to presuppose (or believe outright) that he can observe himself serving coffee or that he has reason to believe that he is doing anything (as an agent). Moreover, why think that he, Kevin, is a person or self? Why shouldn't we adopt a Kantian or Humean or a no-self account of selves defended by Parfit? According to historicalism, Kevin may be sincere, well intentioned, and philosophically astute, but he has not undertaken a serious analysis to be evaluated in terms of our own contemporary judgments and/or intuitions when these are not evaluated in light of the history of philosophy.

Phenomenological realism does not provide us with reasons to ignore the history of philosophy, but it gives us a tool for evaluating past (current and future) philosophy and it has a contextual primacy that provides Kevin with prima facie justification for beginning with his ordinary beliefs about fixing coffee as well as with beginning philosophy with a text from the Creed of Chalcedon.

Consider phenomenological realism and the history of philosophy. Hildebrand does not begin his investigations with a philosophical engagement with Kant, Hegel, et al. Does this position fall prey to the why re-invent the wheel? position or does it conflict with an appeal to humility and solidarity with the past? It is hard to see why when one takes seriously the fact that in the history of philosophy itself, so many philosophers have similarly sought to carry out philosophical inquiry into the nature of the self, perception, values, and so on, without first engaging in an elaborate historical preface. In the modern era, Thomas Reid, Bishop Butler, Franz Brentano, G.E. Moore, Roderick Chisholm and others adopt a method very similar to Hildebrand's. As Chisholm writes in Person and Object: "Leibniz, Reid, Brentano and many other 
philosophers have held that, by considering certain obvious facts about ourselves, we can arrive at an understanding of the general principles of metaphysics." ${ }^{10}$ Hildebrand's work is clearly in the same tradition as Chisholm's. So, going back to the two reasons behind historicalism, it may be argued that the history of philosophy is more like discovering different ways to travel rather than inventing and re-inventing wheels. Each generation can learn from the past, but each generation of philosophers also needs to test their own views (and the arguments of the past) in light of their own experience and reflection.

In my view, phenomenological realism turns out to be in solidarity with the past - given that philosophers of the past also appealed to their own experience and reflection to advance their own positions. According to Hildebrand himself, he is adopting a model of philosophy that goes back long before Chisholm to at least Aristotle who, while he gives some attention to his philosophical forebears Aristotle summarily dismisses their views when it comes to him developing his own philosophy:

I want to start with the moral experience itself. In the same way Aristotle, speaking about the soul, says at the beginning of the second book of his De Anima:

"Let the foregoing suffice as our account of the views concerning the soul which have been handed an by our predecessors; let us now dismiss them and make as it were a completely fresh start, endeavoring to give a precise answer to the question, What is soul?"11

Following von Hildebrand, I believe that it is through a searching, faithful understanding of what each of us knows as persons that we have good experiential grounds for thinking that the earlier datum (persons reason with each other, etc.) has substantial philosophical importance.

I referred earlier to the contextual primacy of phenomenological realism. Let me fill this out and then propose that the importance of the history of philosophy depends on what may be called philosophical climates.

I propose that the primary context that virtually all philosophers and theologians do assume when engaging in debate consists in a whole series of beliefs and practices that seem indispensable. Here is a sketch of such beliefs and practices:

\footnotetext{
${ }^{10}$ Roderick Chisholm, Person and Object, (La Selle: Open Court Publishing, 1976), 15.

${ }^{11}$ Dietrich von Hildebrand, Christian Ethics, (New York: McKay, 1952), 2.
} 
There are people who engage in deliberation, presenting reasons for why this or that philosophy is more reasonable than some alternative; persons engage each other in conversation and lectures; they read papers; eat meals; breath; go hiking and engage in other forms of exercise; they sleep; develop friendships; make decisions; publish papers and books; make jokes; laugh; cry; they sometimes make love; they are part of various communities; some have children and participate in large family living; some are professors who have students and some are students who have professors, while others are independent scholars. They typically find each other morally responsible for their actions and those of others; they praise some persons for their humility and wisdom and do not admire the arrogant and narcissistic. Sometimes these people go to church to pray or they may pray silently and (not to leave out the obvious) they are born and they will die. Billions of people in the world practice in some religious tradition and, in doing so, some recite creeds, meditate on Holy Scripture, and so on. Some believe there is an afterlife for individuals, some believe that an individual afterlife is possible but not likely, while still others believe that it is not possible for individual persons to survive the death of their bodies. Last but not least, some people prepare coffee for their spouses and quite a large number of persons adhere to the Creed of Chalcedon.

I suggest that recognizing the above is practically indispensable as commitments of persons in community. Arguably, it would require extraordinary reasons to deny that billions of people recite creeds or to deny that persons argue with each other, presenting reasons why one belief is more reasonable than another. And, outside of a seminar room or conference in which the topic is Kant's Critique of Pure Reason with a focus on B132 and A352 and/or Parfit's Reasons and Persons, it would be very odd to question whether a philosopher can confidently describe his fixing coffee for his wife or to question the philosophical interest in setting out to see if there might be a philosophical model that makes sense of a creed that millions of people subscribe to. This latter observation about seminar and conference rooms, however, brings up a point that should be made about philosophical climates.

In the final section of this paper, I will argue that Hildebrand's phenomenological realism has some important cultural implications in terms of supporting a just, pacific, democratic republic. But for now, I suggest that such a democratic outlook is compatible with the specialized practice of philosophy in which Kevin (in our original 
thought experiment) truly does owe a response to Kant, et al. That is because certain sites may be constructed that are dedicated to Kant et al. In such a site, there is what may be called a philosophical climate that needs to be addressed. Different sites will come with different conditions that need to be taken on board. One need not address Wittgenstein's private language argument at a meeting of the Hume Society, without there being special conditions that would make this fitting. But consider a conference or a site dedicated to the philosophy of divine and human nature, and not one dedicated to Kant or Parfit on divine and human nature. I believe that there are enough of what appear to be good "common sense" reasons for objecting to the Kantian and Parfitian arguments so that Kevin (in our thought experiment) need not halt his work to make important contributions to Kant or Parfit studies.

Consider, first a Kantian objection; I indemnify this as 'Kantian' in order to indicate that it is derived from a standard interpretation of Kant's work, without getting tied up in the details of Kantian texts and multiple non-standard interpretations. Here, then, is a Kantian objection: strictly speaking, you do not observe yourself because (unknown to you) there might be an undetectable switching of selves such that (rather than you enduring over time as the self-same person) you are a series of selves, constantly being switched and your memories and apparent continuous consciousness perishing and being re-created. Obviously this is painfully succinct (an historicalist will probably see such a summary as horrifying), but it is one reasonable and widely recognized line of reasoning many find in Kant's work. ${ }^{12}$ The Kantian counter-point faces an avalanche of objections: for reasons lying in the philosophy of time (we must endure in time in intervals, not from instant to instant as an instant takes up no time whatever), the switching would have to take place during intervals. How long would these be? If very brief (a Nano-second) then you would be (strictly speaking) a different self who finished reading these sentence from the one who began reading it. In fact, you might be the hundred billionth self in the series. This hypothesis seems to collide with any apparent phenomenological understanding of the experience of thinking and speaking. Speaking of series, if a self is constantly being switched, how would one come up with the experience of series or successive changes (like listening to a song)? Even Kant recognized

\footnotetext{
${ }^{12}$ See, for example, J. Bermudez, "The Unity of Apperception in the Critique of Pure Reason," European Journal of Philosophy 2, no. 3 (1994): 213-40.
} 
that a series of experiences is not the same thing as the experience of a series. ${ }^{13} \mathrm{I}$ believe that the prospect of undetectable switching should no more dissuade Kevin from believing he is the same person who is brining Allison some coffee on Monday as him bringing her coffee later that day than he should be skeptical that he is carrying the same cup of coffee because God might be continuously annihilating the coffee and re-creating it.

What about a Parfitian objection - should it prevent Kevin from using his common sense case in his philosophy of human agency? Parfit, like Hume, faces the objection that he is unable to do justice to the overwhelming awareness each of us has as persons who experience and act in the world as subjects and who live and move and have our being from a first-person point of view. Kevin does not need to, nor could he, identify himself (his thoughts, actions or his body) using indexicals (this is my body) without having an antecedent understanding of himself as an enduring subject. For him to think and intentionally to act on the desire to bring Allison a cup of coffee he needs to be able to think and act as the self-same individual who is providing another individual person a beverage. Imagine a Parfitian world in which Kevin is not a self but a series of causally interwoven physical and mental events. Arguably, an event is not itself something that is conscious. Persons or things are conscious; events may involve conscious persons or organisms but an event itself has no conscious awareness. ${ }^{14}$

These worries are not sufficient to dissuade someone committed to Parfit's philosophy of mind, but they do express prima facie real worries that a Parfitian needs to address and they provide some reason to think Kevin's work is not discredited (or tarnished) until he has more fully addressed Parfit's no-self account of the self.

I believe that essentially the same scenario obtains when Kevin turns to the Creed of Chalcedon and he meets with the objection that he has not addressed the work of Schleirmacher. If Kevin is presenting his work to

${ }^{13}$ In The Critique of Pure Reason A364N, Kant hypothesizes that after a protracted period of time, a self might think it has endured over a series of events, but all that has happened is that a the data of a series of selves with their conscious states (selves who have ceased to be and been successively replaced then ceased to be and then replaced, etc. have been transmitted to the self at the end of the series.

${ }^{14}$ For an extended treatment of the objections I am raising to Kantian and Parfitian arguments see the excellent book, The Conscious Self by David Lund (New York: Humanity Books). 
a scholarly society dedicated to the work of Schleiermacher, then I believe that the philosophical climate demands attention to Schleiermacher. In that domain, it would make greater sense to preface the analytical model of the trinity with a critical evaluation of Schleiermacher's appeal to intuition and feeling. It might even be possible to use analytic tools to unpack some of Schleirermacher's monistic tendencies in which individuals remain individuals and yet are bound up in some overall quasi-Spinozist unity. But while analytical philosophy does need to take seriously what I am referring to as philosophical climates, I suggest that the bare existence of such climates elsewhere does not overshadow or render uninteresting a philosopher seeking to make sense of what billions of ordinary people adhere to.

Let us now turn to scientism from the standpoint of phenomenological realism. As noted earlier, let us consider scientism to be the claim that the physical world is all that there is; its contents are causally closed to anything nonphysical; and the explanation for any event is either in the physical sciences or in modes (e.g. the social sciences) that can be shown to supervene on or be explained through bridge laws in the physical sciences. I think that scientism is deeply problematic for many reasons, including the fact that it rests on terms that are profoundly under determined. I shall propose in reply that we lack any clear understanding of what it is to be physical or what counts as physical explanations, and so the thesis of causal closure is suspect from the get-go. Moreover, I propose instead that we have (and necessarily have) a clearer conception of what may be called (by virtually all philosophers "in the game") mental causation than we do of physical causation (which tout le monde treats as causal relations between mind-independent things -events, properties, objects et al). First, let us take stock of the current state of play of scientism in the philosophy of mind.

In Mind and a Physical World, Jaegwon Kim writes:

The shared project of the majority of those who have worked on the mind-body problem over the past few decades has been to find a way of accommodating the mental within a principled physicalist scheme, while at the same time preserving it as something distinctive -that is, without losing what we value, or find special, in our nature as creatures with minds. (Kim 1998, 2)

This position (of a triumphant quasi or near-enough physicalism) may have to be modified somewhat, given the many arguments that have been 
deployed against physicalism in works such as After Physicalism edited by Benedict Paul Gocke, Contemporary Dualism: A Defence edited by Andrea Lavazza and Howard Robinson, and The Waning of Materialism edited by Robert Koons and George Bealer, among others. But there have been, and there still are, an impressive number of philosophers who share, with Kim, a confident picture of the physical world, and a considerably less confident understanding about how to fit in what we think of as mental.

Consider three more philosophers who give primacy of intelligibility to the physical world and physical causation. Daniel Dennett writes: "I declare my starting point to be the objective materialistic, thirdperson world of the physical sciences." ${ }^{15}$ D.M. Armstrong offers this classic, succinct statement of his metaphysical position: "Naturalism [is] the doctrine that reality consists of nothing but a single, all-embracing spatio-temporal system." ${ }^{16}$ Here is Michael Tye's position:

On the naturalist view, the world contains nothing supernatural ... at the bottom level there are microphysical phenomena governed by the laws of microphysics, and, at higher levels, phenomena that not only participate in causal interactions describable in scientific laws but also bear the general ontic relationship to microphysical items as do the entities quantified over and referred to [in] such higher-level laws as those which obtain in, for example, geology and neurophysiology. ${ }^{17}$

In the wake of such positive claims about what is physical, no wonder some philosophers think that the idea of what may be nonphysical is suspect.

Stepping back a bit, how clear a concept do we have of the physical world and how does that match our concept of what many philosophers classify as mental, as featured in the list cited above in this essay: our thinking, conceiving, feeling, seeing, hearing, tasting, valuing, observing, and so on? Contrary to the assumed orientation in philosophy of mind, I propose that our ordinary beliefs and commitments (as revealed in phenomenological realism) offer us no clear concept of what is physical or material and that subsequent philosophical reflection on the world

\footnotetext{
${ }^{15}$ Daniel Dennett, The Intentional Stance, (Cambridge: MIT Press, 1987), 5.

16 D.M. Armstrong, "Naturalism, Materialism, and First Philosophy," Philosophia 8, 2-3 (1978): 261.

17 Michael Tye, "Naturalism and the Problem of Intentionality," Midwest Studies in Philosophy 19, (1994): 129.
} 
and the sciences have not generated any clear consensus on what is physical. Most importantly, I maintain that we cannot even begin to try to understand what is physical unless we can trust and understand our reasoning and conceptual powers, for without these we cannot even begin to consider whether or not mind-independent objects have mass, volume, size, color, odor, sound, taste, sensory qualities of heat (as opposed to heat as in mean kinetic energy) and whether the physical consists in individual things (particles) or events or fields.

Following the lines of phenomenological realism, I suggest that priority of intelligibility and clarity should be acknowledged as the mental, and that none of the above conceptions of the physical (from Kim to Tye) can be any clearer or more intelligible than the mental. This is evident in the case of when the physical is analyzed in terms of that which is inter-subjective or those things which more than one person can (in principle) observe. Such an analysis (that invokes the 'thirdperson' point of view) must presuppose an antecedent confidence and understanding of subjectivity and observation (known in and from the first and second person point of view). No statements of what is physical can be more certain than that which is mental and if it turns out that we should conclude that the mental is physical, this will be due to our confident exercise of intentional reasons, not due to our substituting non-intentional relations for intentional ones. (The latter would be impossible without our ongoing exercise of intentionality.)

Let us review the earlier statements by our various physicalists or near-enough physicalists. In Fales' case, surely our concepts or ideas of "evidence," "physical," "energy," "deviation," "energy conservation" have primacy over what are not concepts or ideas. In response to Kim, I suggest that it is impossible to have a clearer conception of "a principled physicalist scheme" than you can of a "scheme" which, I assume, is a concept or way of conceiving. And Kim's statement as a whole seems to commit him solidly to the reality of the mental; "accommodating" and "valuing," and grasping principles are mental acts. The point may be so obvious as to hardly bear pointing out, but it reveals the inescapable primacy and essential lucidity of the conceptual, the mental or the reality of our thinking, assessing, valuing, and so on, as opposed to what is posited in the sciences. Michael Tye writes impressively of laws of nature, and yet we can have no conception of a law of nature unless we can trust the reality and reliability of our concepts and the reality of mental causation. In this context, 'mental causation' would be evident 
in our grasping laws of nature, of comprehending when it is that certain molecular, atomic, nuclear and subnuclear events cause or explain other molecular, atomic, nuclear and subnuclear events. We only grasp a law of nature if we can trust our reasoning, whether this is cashed out in terms of a covering law model, counterfactuals, or we adopt a philosophy of causation that recognizes basic powers. This involves the use of mental causation insofar as a person grasps the relevant causal relata, and whether the relata is immanent, located in spacetime, or transcendent and non-spatiotemporal, grasping laws of nature involves our reasoning that if certain antecedent and contemporary events obtain then there is reason to believe this will bring about (or cause or explain) another event. The causal elements in the course of a person's reasoning may be vast and complex, but for reasoning to occur, the conclusions a person draws must (in a crucial, ineliminible way) be in virtue of grasping the relevant premises and inferential rules. From simple mathematics in which we reason that the answer is 2 based on our summing $1+1$, to astrophysics, it is essential that we draw conclusions in virtue of grasping reasons and entailments or inferential relations.

While the following seems to be mind-numbingly obvious, it seems to be overlooked or under-appreciated: microphysics, geology, and neurophysiology cannot be practiced unless there are microphysists, geologists, and neurophysiologists, and each of them must necessarily work with concepts, observations, theories, being able to grasp entailment relations, the laws of logic, and so on.

Consider an objection: All that the above reasoning establishes (or makes reasonable) is that we must have facility with our thinking, reasons, and concepts in order to draw conclusions about the nature of the world. It does not mean we understand what thinking is or reasoning or concepts. After all, someone might have no idea whatsoever about what makes a car go, but she can drive it expertly and get anywhere she wants.

Reply: The analogy needs to be pressed further. Imagine that the driver has no idea at all about driving, let along all the particulars involving roads, wheels, petals, traffic laws et al. She must have an idea about a massive number of interwoven practices and how to bring about changes in order even to get into what she rightly thinks of as a car. For her to be agnostic or to profess to having no idea why driving a car involves her knowing what to do seems to border on us imagining a zombie driver. 
What about Philipse and Fales? Both philosophers seem to assume that we have a clear idea of what it is to be physical (material or corporeal) and what is different about physical and nonphyscical causes. Do we? Can we rightly assume that what is physical is solid, dense stuff; it is uniform, made up of distinct particulars, compared to which the non-physical, whatever that is, is spooky and mysterious? Actually, much of 20th century physics seems to lead us to think that the physical world is more spooky than we imagined; consider Bertrand Russell's observation: "Matter has become as ghostly as anything in a spiritual séance." ${ }^{18}$ I suggest that Noam Chomsky is correct that "The notion of 'physical world' is open and evolving" and, as I argued above, that it is not sufficiently precise to use as a lucid alternative to that which is 'non-physical. ${ }^{19}$ Proposals that, for example, being spatial is a necessary condition for being physical seems problematic given the history of philosophers (from the Cambridge Platonists to G.E. Moore and H.H. Price) who treat spatial things and events as non-physical (including the visual field, sense data, dream images, after-images, etc).

Philipse seems to assume some form of behaviorism, requiring a God who hears and responds to prayers to act in ways that are similar to the way we humans listen and respond to one another. Unfortunately for Philipse, even if it is granted that his implicitly anthropomorphic understanding of God is a fair representation of theism, behaviorism seems thoroughly discredited when it comes to humans (the anthropos is anthropomorphic). ${ }^{20}$

In further considering the objections of section one, it is worth noting the peculiarity of Fales' first argument which appears to have this form: if God cannot (or is not?) knowable or discernable scientifically, then God is impotent or unknowable. Imagine we conclude that we cannot know scientifically what Shakespeare meant in all his plays. Would it follow that the Bard is impotent? That seems doubtful. What about unknowable? Perhaps some non-scientific means are sufficient for us to have reasonable beliefs about what the Bard meant. Von Hildebrand thought that we can have some experiential awareness of God and this is of the kind that many philosophers have since come to use in theistic

\footnotetext{
${ }^{18}$ Bertrand Russell, An Outline of Philosophy, (London: Routledge, 2009), 78.

${ }^{19}$ Noam Chomsky, Rules and Representations, (New York: Columbia, 2005), 5-6.

${ }^{20}$ See A Brief History of the Soul by Stewart Goetz and Charles Taliaferro (Oxford: Wiley Blackwell, 2011).
} 
arguments from religious experience. ${ }^{21}$ This, in principle, would provide conditions in which one can offer a phenomenological account of what it is for persons to experience the divine or sacred.

On Fales' demand that a proper theistic account needs to offer an account of how God acts, this again, seems to be an example of anthropomorphism or likening God to a being who is the subject of laws of nature as opposed to their author. In theistic tradition, God is believed to possess divine attributes in ways that are interconnected. I happen to be in the Anselmian or prefect-being tradition and understand God's power, knowledge, essential goodness and the like, as being made evident by God's unsurpassable excellence. I have defended the ontological and other theistic - arguments elsewhere. ${ }^{22}$ Fales's characterization of omnipotence as a purely dispositional property in search of a categorical property is (at least) misleading, insofar as traditional theism sees God's powers (of knowledge and to bring about states of affairs) as basic, and not due to the causal powers of any intermediary. Does this make them obscure or empty? It is hard to see why when one can recognize conceptually explanations in terms of intentions or purposes by created persons that are not reducible to non-intentional and non-purposive explanations. For the sake of argument, let us concede that in actual fact, human beings intentional agency can be reduced to the non-intentional, it still does not follow that such a reduction is necessarily the case so that (a) it could not be otherwise or (b) there could not be forms of intentional agency whose intentions are not reducible. Fales' analogy with magic therefore seems far-off. Theists do not do the equivalent of sneak rabbits into hats. They rather address the very nature of what counts as an ultimate, unsurpassable great or excellent reality; to complain that such a reality or being needs to meet the standards of explanation that befit beings of less excellence seems wide of the mark. ${ }^{23}$

${ }^{21}$ See, for example, The Rainbow of Experiences, Critical Trust, and God: A Defense of Holistic Empiricism by Kai Man Kwan (London and New York: Continuum, 2011).

${ }^{22}$ See Contemporary Philosophy of Religion by Charles Taliaferro (Hoboken: WileyBlackwell, 1998).

${ }^{23}$ For an overall look at the relevant philosophical domains, see The Routledge Companion to Theism ed. by C. Taliaferro, V. Harrison, S. Goetz (London: Routledge, 2013). Fales' demand for the means by which God acts reminds us of cases when philosophers insisted that we cannot explain human volition without positing some intermediate such as a higher order volition to have a volition, and so on ad infinitum. Many philosophers of human agency make use of the notion of basic acts, which do not 
By way of a further defense of divine and human agency from a theistic point of view, consider a final barrage of three, interrelated objections concerning the project of this essay and a summary response.

Objection one: Appealing to phenomenological realism only expands a list of what needs to be explained scientifically. Science has shed enormous light on our intentional action. But what further science can shed light on divine agency? The scientific inscrutability of divine agency shows theism to be anti-scientific.

Objection two: Appealing to phenomenological realism entrenches us in the status quo of ideas and ideals. It used to be common sense to appeal to demon possession. Surely we need a better alternative.

Objection three: Phenomenological realism gives us data that is thoroughly neutral in terms of the deep philosophical theories historically and in our own time. Imagine evaluating a Spinozist metaphysics and epistemology in light of phenomenological realism! There is a long tradition of philosophers who think that some metaphysic or epistemology is true or well grounded, but it cannot work in the life of practical engagement. David Hume realized he needed to play backgammon from time to time to escape his reasoning and conclusion in the study, but that did not give him a philosophical reason for thinking his ruminations in the study were spurious.

On the first objection, it is obvious that the natural sciences (especially brain sciences) along with the social sciences have shed a great deal of light on human agency, but none of it has given us good reason (in my view) to adopt a reductionist or identity theory of the mental. This is partly due to the problem of even knowing what is physical, but it is also due to the important difference between the sciences establishing correlations of the mental and brain and other bodily processes and events versus identity. The inescapability of the mental actually provides us good reason for thinking that practicing neurologists implicitly presuppose a form of dualism, even if they profess otherwise.$^{24}$ As noted above, the fact that theistic explanations do not yield scientific scrutiny (identifying what mechanisms God uses when God acts) is no more

require further volitions or intentions. See, for example, Person and Object by Roderick Chisholm. La Salle: Open Court, 1976.

${ }^{24}$ This is made evident in the essay "Neuroscience: Dualism in Disguise" by Riccardo Manzotti and Paolo Moderato from Contemporary Dualism: A Defense (London: Routledge, 2014). 
reason to dispense with theistic explanations than we would have reason to dispense with explanations of mathematical propositions in terms of logical entailment because such explanations are non-biological. As many have argued, there is reason to think theism provides a foundation for science and, from such a point of view, it is anything but anti-science. ${ }^{25}$

Two, phenomenological realism reveals our use of reason to be self-correcting and providing a foundation for the critical investigation of the credibility of our beliefs. The legacy of von Hildebrand is an ongoing, rigorous self-criticism. As a matter of historical significance, von Hildebrand's philosophy led him to radically oppose the status quo of his society, risking his life facing up to anti-Semitism and fascism in Europe.

Third, I propose that Spinoza and Hume (and their progeny) do face some prima facie objections as revealed in phenomenological realism. Spinoza does need to provide reasons (and he actually does so) for why we should set aside what appears to be our experiential awareness of our possessing powers to make changes in conditions that are contingent. Hume does need reasons for adopting the bundle theory of the self, his view of causation and our observations about the world, and (to his great credit) he offers such reasons. By providing some reasons in this essay why Kevin does not need to stop practicing his philosophy of human and divine agency in order to first engage Kant and Parfit, I am not denying that Kant and Parfit have provided us with rich and intriguing arguments we should pursue on their own. The thrust of this essay is not at all antiphilosophical; it is simply a matter of knowing what philosophers need to do in order to successfully make their case in specific projects.

Limitations of space requires that I refer readers to where I have employed phenomenological realism to explicitly support a nonreductive account of human persons and divine agency. I develop this most recently in The Image in Mind, which extends considerably an earlier project of defending what I call integrative dualism and integrative theism. ${ }^{26}$ In the space remaining, I propose to make an observation

${ }^{25}$ In The Routledge Companion to Theism, see the entries on Naturalism, Natural Sciences, Evolution, Physical Cosmology, Psychology, Cognitive Science.

${ }^{26}$ See The Image in Mind co-authored with Jil Evans (London: Continuum, 2010) and Consciousness and the Mind of God (Cambridge: Cambridge University Press, 1994). A reviewer of an earlier version of this essay asks how one might settle disagreements among phenomenological realists. Imagine one phenomenological realist reaches the conclusion that libertarian agency is right, whereas another concludes with compatabilism. While there is no convenient algorithm to decide matters, I suggest 
about the cultural significance of our philosophical methodologies and, in particular, the significance of phenomenological realism.

\section{THE CULTURAL SIGNIFICANCE OF PHENOMENOLOGICAL REALISM}

What do historicalism and scientism have in common? In a sense, both are elite positions insofar as both require advanced education in the humanities and sciences respectfully. Ordinary persons do not worry about Kant's argument about the possibility of undetected switching of themselves. Nor does the everyday person suspect that their purposes, desires or even consciousness itself may not exist. Phenomenological realism, in contrast, treats our everyday, apparent conceptions of ourselves and the world as real and trustworthy, subject to critical review. A good example of this involves our experience of the world in color. A phenomenological realist may well (as I do) come to conclude that mind-independent objects do not have the colors they appear to as intrinsic properties of the objects themselves, nonetheless the evident experience of color gives us very good reason to resist the effort to deny that persons actually experience color (or those who deny that subjective experiences of color do not exist). Because Hildebrand, and other phenomenological realists, promote a philosophical method that takes seriously our ordinary experience there is a sense in which it is quite natural that Hildebrand promoted the widespread practice of philosophy in culture in which ordinary persons may be drawn to the practice of philosophy as the love of wisdom. Arguably, among persons who sincerely pursue the love of wisdom with a balance of courage and humility, there will be great resistance to intellectual manipulation, an openness to the reasons of others, the fostering of alternative viewpoints in which persons may freely assess and critically review. In my view, Hildebrand's phenomenological realism, implemented culturally, would naturally be very much in line with what Karl Popper describes as the open society.

that we distinguish between a phenomenological analysis of agency itself (the firstperson awareness of oneself when acting) and our commitments or convictions on the level of theory. Although it is impossible to argue for this here, my own view is that we do experience ourselves as agents in a fashion that gives evidential presumption to libertarianism, however this prima facie justification can be overcome by theoretical reasoning supporting determinism and compatabilism. For the record, I think the prima facie evidence favoring libertarianism is not defeated by further philosophical reflection. 
In this respect, phenomenological realism is helpful in promoting what may be called the philosophical ground for an open society.

Hildebrand had an outstanding record as an opponent of the enemies of an open society. He was an early and sustained opponent of fascism and anti-Semitism before and during World War Two. Hildebrand was a German citizen, though born in Italy who had to flee Nazi forces, moving from Germany to Austria, then to Switzerland and eventually to the United States. His opposition to Nazism was especially dangerous in terms of his personal security in Austria. The Nazi ambassador to Austria, Franz von Papen wrote "That damned Hildebrand is the greatest obstacle for National Socialism in Austria. No one causes more harm" and he proposed that Hitler order the assassination of Hildebrand, "the architect of the intellectual resistance in Austria." ${ }^{27}$

I do not suggest that historicalism and scientism should be rejected because they are elitist or that phenomenal realism should be adopted because it promotes a democratic culture. But I do suggest in closing that in our reflections on the philosophy of divine and human nature, we take into account the cultural implications of our philosophical methods. For practical persons, it is impossible to see historicalism or scientism as the mainstay for mainstream cultural exchanges. There are and should be special sites for specialized historical and scientific inquiry. But there are also good reasons for those of us who are philosophers and theologians to promote a philosophical foundation that supports an open society in which these more specialized pursuits can flourish.

Acknowledgement. I thank all those who have helped with my reflections on phenomenological realism, including Georg Gasser, Johannes Groessl, Lukas Kraus, and all those who attended the conference "Divine Action in the World: Philosophical and Theological Inquiry".

${ }^{27}$ Dietrich von Hildebrand, My Battle Against Hitler (New York: Image, 2014). 